\title{
Miguel Angel Asturias y el Teatro
}

La obra dramática de Miguel Angel Asturias, escrita muy recientemente y suscitada por el estímulo de la rica vida teatral de Buenos Aires -ciudad en la que vivió durante largos años- nos muestra al escritor en una doble dimensión; la del polemista que hace uso del diálogo dramático para acendrar sus ideas de orden social y político y la del poeta que pretendía recoger en imágenes vivas y corpóreas algunas de las sugerencias mágicas que provienen de las culturas prehispánicas. Sin el dominio de un verdadero oficio de autor dramático, Asturias se acercó al teatro de manera decidida, dispuesto a dar estructura a algunas "visiones" que habian sido expresadas en forma dialogada en las Leyendas de Guatemala, formas teiterativas, más adecuadas a la evocación, a la invocación mítica que a comunicación de un conflicto limitado, que halla curso dentro de su propia problemática, como el teatro lo exige.

Es necesario puntualizar que no siendo Asturias un hombre que ha vivido el teatro "desde dentro" su preocupación por la dinámica escénica es casi nula en sus textos. O ésta ha sido paralizada para dar un amplio desenvolvimiento al discurso, o en otras ocasiones el esquema se precipita en la acumulación de imágenes que encuentran un difícil cauce de exposición sobre el escenario. $\mathrm{Y}$ dentro de estas limitaciones debemos examinar sus obras teatrales, para poder desentrañar todo lo que hay en ellas de hallazgo instintivo, de poesía no teatral, que al mandato de una potente imaginación creadora puede despertar en un director de escena hábil y diestro la forma escénica propicia para comunicarla.

En primer término y como fenómeno general se advierte en estas obras una dificultad para administrar el crecimiento de la acción dramática, lo que suele llamarse la "progresión" del conflicto. Y este hecho malogra en algunas ocasiones la situación en que el autor sitúa a sus personajes, pero también nos permite apreciar su rica y desbordada invención, de la cual el ditector puede seleccionar lo más significativo, lo que el autor ha dejado pasar inadvertido. El pecado capital de Asturias en 
su creación dramática es siempre un exceso, y bien sabido es que de los excesos puede limpiarse el teatro en el momento de la representación. Lo único insalvable es la falta de imaginación, la ausencia de trasfondo poético dentro del conflicto que nutre a una obra teatral.

Además de las leyendas dialogadas a las que anteriormente aludiamos, entre las cuales "Cuculcan" ocupa un lugar único por la visión plástica del ámbito natural exuberante, Asturias ha escrito su obra dramática ceñido dentro de dos cauces paralelos: Uno de ellos es el que pretende aleccionar acerca de los peligros que se ciernen sobre los países "subdesarrollados"; el otro, el que actualiza en la realidad guatemalteca los acentos permanentes de la cultura ancestral.

Dentro de la primera modalidad sorprende su obra Cbantaje, cuya acción transcurre "en un país de la América tropical". La fábula simple y directa, un tanto descarnada, desposeída de todo misterio, se inscribe en la corriente expresionista, o al menos en los aspectos didácticos de ésta. El conflicto está constituido por la amenaza oculta detrás de las fuertes aportaciones capitalistas que, justificadas en las transacciones petroleras, van intoxicando lentamente la vida de ese pequeño país.

Los personajes incidentales transitan por la obra sin rumbo, como ilustraciones de la amenaza general: la deshumanización de un pueblo. Un numeroso contingente de presencias genéricas ejemplifican a los diferentes sectores de la población del mundo de hoy, para concluir en una denuncia en contra de la estructura capitalista. El lector resiente la ausencia de los elementos más trascendentes del Expresionismo: la crueldad como función inevitable del ser humano y no sólo de un sistema, la confrontación permanente entre los valores de libertad y responsabilidad que definen a los personajes más característicos de la modalidad expresionista. Chantaje en su contexto general asocia diálogos, soliloquios y voces colectivas de manera indiscriminada y en su desorden advertimos el caos que el autor desea poner de realce como sinónimo de la sociedad burguesa contemporánea.

También en esta línea de observación y de exposición dramática Asturias escribió Dique seco, pero en esta obra el juego se manifiesta más limpio, más sincero y menos reiterativo, gracias al humor que opone el socialismo ante el capitalismo de manera simplista y tajante, pero que imprime un acento popular de fuerte y saturada ironía a la crítica social. De esta manera, en medio de una trama en cuyo asunto central nos presenta a un marqués falsificado y sus desventuras por conservar o preservar su imagen, hace acto de presencia el sentido del humor desvalido del pueblo de Guatemala, que descarga de gravedad a los más dramáticos 
acontecimientos, como una forma de defensa ante los sucesivos agravios sufridos a lo largo de su historia.

Mejor motivada y construida, con una mayor nobleza verbal, empaque recio y conclusiones menos inmediatas es $L a$ Audiencia de los Confines, obra en la que Asturias expresa una problemática más intima y cercana a sus preocupaciones más profundas. El drama presenta los primeros instantes de la convivencia indohispánica después de la Conquista, las tensiones y sublimaciones ocasionadas por esos primeros encuentros. Para ello el autor se ha valido de dos "planos" en los cuales transcurre Ia acción dramática; uno español $\mathrm{y}$ uno indio. Ambos parecen tener vida autónoma, peto lentamente sus ámbitos vitales van entrecruzando influjos, presencias, ideas y consecuencias. Con moderado espiritu cristiano el autor destaca la figura de fray Bartolomé de las Casas, que establece la comunicación y el equilibrio entre los dos términos escénicos de la obra. Aquí vemos ya un conocimiento mayor de las limitaciones del teatro, de sus exigencias y de la grandeza que deriva de esa limitación. El autor logra decir mucho en espacios económicos y aunque los personajes son más bien "tipos" que caracteres explorados en su psicología individual, el contenido general de la obra es actual y eficazmente dramático porque nos presenta el conflicto establecido entre dos formas de vida que coexisten en Guatemala: el mundo mágico aún presente de los indígenas $\mathrm{y}$ el racionalismo occidental que pugna por penetrar ese misterio y por establecer cauces humanísticos a la existencia.

La obra más importante que Miguel Angel Asturias ha escrito para el teatro es Soluna. En ella encontramos, concentrados, los valores más permanentes de toda su creación literaria, aun cuando la forma y las rupturas abruptas del ritmo dramático puedan suscitar algunos desconciertos. La "comedia prodigiosa en dos jornadas y un final", como su autor ha llamado a esta obra, transcurre también en un ámbito de doble dimensión. En el más superficial e inmediato, el que podría recordarnos un sainete costumbrista, vemos a un hombre y su mujer terratenientes guatemaltecos que tratan de escapar de las formas de vida del campo. Aparentemente esta inconformidad está motivada por el aislamiento y la idealización que la mujer ha hecho de la ciudad en la que desea vivir, pero en el fondo el verdadero temor es el de enfrentarse con las formas de vida, inexoraibles, de sus antepasados indios. Paralelamente a este conflicto banal transcurre otro, el de los sirvientes indígenas que en medio de premoniciones, conflictos intangibles y mágicos, amenazas expresadas en signos cabalísticos y misteriosos, tratan a su vez de vivir en medio de ese diario combate establecido entre el sol y la luna, a lo largo del recorrido solar, 
de su dominio y su plenitud repetidos a lo largo de los tiempos inmemotiales. La presencia del "nagual", símbolo del animal que todo hombre lleva dentro, reminiscencia de la representación del mal, proveniente de las culturas indias, inscribe el conflicto en un orden extraterreno de sofocada e inflexible fatalidad. La escena culminante del drama trae al escenario a los hombres del sol y los de la luna que se mueven en una danza precipitada de extrema belleza plástica y rítmica, y que rodean a los personajes de la comedia para envolverlos en una densa atmósfera mítica. Con Soluna Asturias ha vuelto a hacer activo ese material dramático del Rabinal Acbi, en el cual los hechos se reiteran sin medida, sin atender al interés dramático mismo, a su crecimiento y sus conclusiones para convertir el teatro en un acto litúrgico que trasciende la razón y que recuerda el secreto titual de todos los actos cotidianos, los signos fugitivos, ocultos detrás del diario devenir de los hechos ordinarios.

El escritor guatemalteco llegó al teatro en estos años recientes de su fértil vida literaria. Con briosa madurez emprendió uno de los caminos más arduos de su experiencia como escritor; el de conciliar los espacios que el teatro dedica a la acción con los que reserva a la reflexión. Si en algunas de sus obras el equilibrio total no se ha logrado, quizá sea por esa falta de "costumbre" que conforma un oficio aprendido desde los inicios de una vida y de una creación literaria.

Universidad Nacional Autónoma de México

CARLos Solórzano 